\title{
Stigma Diagnosis and De-Institutionalization of the Mentally Ill Criminal: A Case Study
}

\author{
Francisco Ramos de Farias, José Mauro de Oliveira Braz \\ Federal University of the State of Rio de Janeiro, Rio de Janeiro, Brazil \\ Email: frfarias@uol.com.br
}

Received 11 March 2014; revised 12 April 2014; accepted 8 May 2014

Copyright (C) 2014 by authors and Scientific Research Publishing Inc.

This work is licensed under the Creative Commons Attribution International License (CC BY). http://creativecommons.org/licenses/by/4.0/

(c) (i) Open Access

\section{Abstract}

This study focuses on issues concerning treatment in penal institutions determined by mandatory commitment and the problems relating to the release of adults with mental health disorders who have been committed. The analysis was based on the provisions of Act10216, which determines the end of hospitalization in psychiatric institutions. It then looks at the situation of Maria dos Anjos, a released person currently being sheltered at the Heitor Carrilho Hospital, a custodial institution in the city of Rio de Janeiro. These institutions are spaces of many contradictions, considering their hybrid setting: the coexistence of the medical apparatus, the security apparatus and the legal division. Treatment is often hindered by legal decisions and therefore in conflict with collective health policies. We have raised the following questions: How should these people be released considering the precarious situation of the mental health services? And what will happen to them with the end of these institutions?

\section{Keywords}

Release, Criminally Insane, Mental Health

\section{Introduction}

The field of social practices, in the context of the history of mankind, produced several categories of different beings, some of which were integrated positively to the social context, whilst others were excluded. The criteria by which some different beings were enrolled, socially, in a negative or positive form, varied according to traditions and customs, at different moments in time: dwarfs were used for entertainment; some forms of physical deformities were displayed in circuses and public squares; madmen were considered to be endowed with a divine aura and to be fortune tellers. Obviously these categories coexisted in the cities and within families as long as they did not present any form of questioning nor caused any type of disturbance. However, when certain groups of different 
beings started to generate social tensions they began to be perceived negatively and became objects of segregation and elimination. Those practices have followed the social and current guidelines of those times according to which, for instance, some people who were born with some sort of deformity or disability was seen as an incarnation of the demon; likewise, the addicted, the mentally ill and the left-handed would be considered embodiments of the evil. The exclusion of those who cause discomfort to society is a human trait that stems back to the history of mankind. Historically, those who are a bother, for whatever reason, were and still are segregated from the social context, in the belief that, once one is distant from the different beings, one would be getting rid of evil or damaging influences. The segregation, however, was valued as asepsis and also protection: it was necessary to create barriers to separate what was acceptable from what was supposedly considered disturbing. But what was considered disturbing? Both the individuals that caused social disorders with fights, disagreements, addictions and bad habits; and also those who had physical deformities, signs of teratological effects and deficiencies, indicating to society the existence of unwanted aspects which were recriminated and dreaded, should be kept away, maintained under strict control and eradicated at all costs.

\section{Literature Review}

As one scrolls through the history of the segregated, in the Middle Ages, according to Foucault (1996), one perceives a greater concern regarding this question, mainly due to the emergence and rapid spread of leprosy. Not that leprosy was feared, but the lepers themselves were discriminated and subjected to violent actions. A measure took place: the creation of leprosaria aiming to separate lepers from the rest of the population to avoid the proliferation of this disease. By the end of the Middle Ages, leprosy disappears from the Western world, resulting in a number of establishments without use. Nevertheless, the authorities of the time tried to give a new use to such sites. If these establishments previously had the purpose of segregating; they were kept for the same purpose, only changing the category of those segregated. In this scenario arose the general hospitals in places of the ancient leprosarium, with areas of exclusion destined for venereal diseases carriers, for the poor, vagabonds, for prostitutes, alcoholics and the so-called alienated minds; a category that is later segregated as insane. The process known as the great hospitalization had the purpose of neutralizing the undesirable characters within the social sphere due to their different mode of being and aimlessly left by their families. They were institutionalized as being insane or morally frowned upon. The inclusion of these categories in institutions contributed to the saturation of these places, and to the inconformity of certain groups, thus beginning the construction of new establishments of segregation. Initially the insane and all other undesirable categories were placed in a same space. Curiously enough, the insane themselves demanded a space more suitable for their treatment, by not considering suitable mixing with other categories, in addition to the prevailing culture of these establishments which was guided by a moral framework, striving for the correcting of bad habits and excessive passions. This stemmed the emergence of differentiated spaces, among which the asylum for the insane.

With regard to insanity, taking into consideration the different conceptions in terms of conflict with moral values, mental disorder or social maladjustment, the measure concerning the exclusion from social context, until recently, was justified as a strategy which aimed at the cure and control of certain individuals, considered dangerous by the fact of endangering their own life or the lives of other people due to their crises. It is important to note that definitions of insanity vary according to the perceptions and representations of each era, throughout the history of humanity, being re-signified as injunctions of social and political order. In antiquity, madness was thought of as being related to the intervention of the gods, having a mystical connotation (Santos, 2010). In the Middle Ages, the idea of a punishment, originally attributed to leprosy, spread to insanity. According to Castro (2009: p. 52) "with the development of the natural sciences and the increased strengthening of a science, based on the positivist ideals of the 17th century, a scientific revolution occurred, which marked a rupture with the scientific and philosophical conceptions that existed at that time" about insanity, thereby partly ceasing to be interpreted within the domain of demonic forces, moving towards an objective causality.

With the contribution of anatomists, in the dissections of corpses, the concept of lesion was established; explanatory basis of all diseases, including those of the psyche (Foucault, 2011). This same line of reasoning is conveyed to the field of criminal actions. In this sense, one of the developments of this revolution is the advent of Criminal Anthropology by Lombroso (2007: p. 10) for whom "the criminal is genetically determined towards evil, for congenital reasons.” The attempt to determine this congenital trend concretized with the application of anthropometric measures of specific body parts such as the skull, jaw, among others. Considering the advancement of 
positivist ideals, madness becomes seen as a disease capable of control, segregation and treatment. It is worth pointing out that the influence of Lombroso's studies found echo in the diagnosis of the first insane individuals who were hospitalized. Given the historical portrait of the exclusion process of segregated individuals, one focuses madness in modern times, climax of confinement for treatment.

The same process of segregation also occurred in the context of crime with the advent of modern prisons, where prisoners are confined, not waiting for punishment but rather to be corrected and penalized by restriction of liberty. Thus, two types of isolated segregation institutions were configured: one for the insane and another for criminals. The incursions of medical knowledge however, within the medical legal practices, in the late 19th century, changed that scenario. This initiative resulted in the venture aimed at reducing medical recourse to the judiciary, backed up by Social Sciences (Donzelot, 2001). From the intersection of medical knowledge with the scope of legal practices, according to Pinto, Farias and Gondar (2012), emerged the category titled insane criminal or insane offender, which has already been through several names changes until most recently becoming: adult individuals with mental disorders in conflict with the law. In a sense, "justice will surround itself with the knowledge of medicine and Psychiatry to carry out its project of control and moral reform of individuals.” (Neri, 2009: p. 115) The production of this category created conditions for the foundation of the institutions that were supposed to treat them, but under control and surveillance; being the reason why its members are doubly stigmatized: criminals and madmen, confined in hybrid locations that mix prison with hospital; custody with psychiatric treatment. Hence the birth of the forensic psychiatric hospitals, currently referred to as judicial hospitals for custody and psychiatric treatment. In this sense, Carrara (2010) states that, in such locations, a hybrid category is found, that brings together two dark sides of existence, crime and madness.

Although we know that, according to Fry (1982), initially, the insane and the mentally ill criminal lived together in hospices, the advent of this last category and their inadequacy to prisons and mental institutions resulted, however, in several dead ends, being the reason why, on many occasions, the mentally ill criminal was forwarded to their families by Court determination. That meant that the segregation institutions could not handle this category of socially excluded individuals. Despite this measure, society called for the creation of a place to control this newly formed category. Besides, as the practice of crime was justified by a morbid psychic state, it was necessary to consider treatment. For this reason, amongst others, as demonstrates Carrara (1998), a third type of institution for mentally ill criminal segregation emerged: the judiciary mental hospitals, which operate as appendices to the prisons or specific constructions. However, although they were created to look after and treat the mentally ill criminal, these institutions reflect the practice of exclusion and segregation where the extremes of undesirable characters are placed. It should be noted also that, although the mental hospitals had been designed "to house in general, any mental or insane individual who committed crimes; they were more especially for criminals considered as degenerates by birth or nature, or, more broadly, morally anomalous.” (Carrara, 1998: p. 195)

Social exclusion of the referred category results in dynamics that involve several phases: 1) the individual after having committed a crime, if arrested, is subject to a police report, made in police stations, on the basis of which he may be declared a criminal; 2) subsequently, during the inquest, the individual under suspicion, at the discretion of the judge or other professionals, may be subjected to a forensic examination to provide information about his mental state at the time the crime was committed; 3) should the existence of a mental disorder be evidenced, the individual would be considered, in terms of the motivation for the crime, as having a mental disorder, that is, if the examination data reveal the momentary absence of critical judgment in the assessment of the consequences of committing the crime. The production of expert reports aim to raise information about the dynamics of criminal acts and their motivations. In this sense the forensic examination is constituted by legal determination as being "an inquiry regarding the agent, focusing beyond the crime committed, representing a test subjected to technical schemes of greater depth in the morphological, functional and psychological fields.” (Wolf, 2005: p. 149) In the process of forensic assessment, medical knowledge interferes decisively within the scope of juridical knowledge when a mental disorder of the criminal is highlighted and presented as a causal link for having committed the crime. However, despite this type of evaluation having a high degree of credibility in the sphere of legal knowledge, they are not always reliable predictions, even when bringing tangible outcomes regarding the fate of the subject (Rauter, 2009). Then, due to the security measures, the subject is incarcerated in a mental hospital and gradually becomes, following the norms of the asylum system, the basis for the diagnosis of madness since, in addition to being marked by the stigma of being dangerousness due to the crime, is also stigmatized, according to Mattos (2006). In addition to embracing our look at the category of mentally ill criminals, we also consider the institution intended for their treatment as a place of memory construction. Nevertheless, these looks converge 
toward the construction of their social memory; ethical and political concept, as well as polysemic and transdisciplinary (Gondar, 2005). In this spirit, we will reflect upon one of these institutions with regards to the construction of its memory, considering the reproduction and organization of the facts that make up its story. It is a delicate process of investigation into the memories that are disseminated within the various environments of the institution and also the stories built up over nearly a century of existence: the Hospital Heitor Carrilho; the first institution of Brazil and Latin America (Forti, 2009), devised along the lines of operation and European principles prevailing in France and England. It was founded in the second decade of the twentieth century, in the city of Rio de Janeiro, in an adjacent building to the House of Correction of the Court, known as the Frei Caneca Street prison complex, demolished in 2009. Nevertheless, the Heitor Carrilho Hospital could not be demolished due to a federal law which classifies the hospital as being intended for healthcare.

It should be noted that, in addition to this peculiarity, that is, the building may only be used for the mental health sector, the moment that the institution is going through is very critical, which is extremely important in terms of building its memory. Yet another circumstance must be mentioned: the hospital no longer incarcerates mentally ill criminals, being only the outlet door for hospital discharge, a policy that is being duly carried out. For this reason, the management team and other employees are being changed by the "new" function; some of which even participate directly in the process of the hospital discharge. Thus, this movement of the institution appears as being unique in its history. It is believed that this policy is striving to reverse a process that has taken shape in World War II, that is, as pointed out by Mousse (2008: p. 3) "the problem of reification of individuals with mental disorders, reappears when other reports start to be made.” Amongst these reports, lies the scientific research undertaken with the population of inmates in the forensic psychiatric hospitals and the mental institutions. In this same context, the practice of segregation, or asylum practices, in Psychiatry begins to be questioned. Such questioning starts to arouse a series of attempts to modify psychiatric institutions, where these, at first, proposed a humanization of the treatment of inmates, even so, however, it was perceived that such a practice would not solve or alleviate the suffering of these individuals. That was when a logical process began to be developed based upon the democracy of relationships, the participation and the therapeutic role of all members of the community, with emphasis on communication and the workplace, as essential instruments in the recovery process of the inmates. In this spirit, the forensic mental hospitals, by also being psychiatric institutions, become a target of repercussions of the psychiatric reform which culminated with the end of the asylums for the hospitalization of the insane.

The psychiatric reform arrives in Brazil already with the changes related to hospital discharge. The national policy for hospital discharge begins at the outbreak of the sanitary health movement during the 1970's and which presents itself within an international context aimed at overcoming asylum violence. The great innovation of this reform, according to Mattos (2006: p. 211) "is to consider hospitalization as exceptional measure and short-lived, in any of the predicted forms (voluntary, involuntary and judicial) since it was necessarily linked to moments of severe crisis." The movement of the psychiatric reform translates into a complex political and social process, composed of actors, institutions and powers of different origins, and which act in different territories and in all spheres of the government. The reform is understood to be a set of transformation of practices, knowledge, cultural and social values that should happen in the everyday life of the institutions, the services and the interpersonal relationships. In this sense, the reform process progresses, but marked by deadlocks, tensions, conflicts and challenges, being one of its achievements the adoption of the Law 10.216 of 2001, sanctioned after twelve years of proceedings in Congress, and which provides for the protection and rights of people with mental disorders redirecting the mental health care model. The consequences of this law were reverted into actions, implemented by the Government, within the national territory, in the form of experiences resulting in the creation of Psychosocial Support Centers; intensive care units for people with serious psychic distress and the creation of Psychosocial Care Nuclei, spaces that are essential references for the implementation of services aimed at the substitution of mental asylum treatment (Castro, 2009). Despite the law 10.216 having been a huge advance in the context of the Brazilian institutions, and heading towards the social reintegration of persons suffering from mental illnesses, it presents a content targeted at people with mental disorders in general. For this reason, its applicability encountered barriers regarding implementation related to mentally ill criminals. Due to these difficulties, the resolutions 05, dated May 4, 2004 and 04, dated July 30, 2010, were issued, and deal with the attention to the mentally ill criminals and the application of security measures. Regarding the security measure, its purpose is the legalization of hospitalization, to care for the safety of the individual and of society.

The security measure established by law, within a time interval that should not exceed three years, can be renewed, depending on the results of the forensic tests regarding the termination of dangerous behavior. However, 
"the only possible way to exit the labyrinth of the security measures, by judiciary diction, implies necessarily on the miraculous and oracular termination of dangerous behavior.” (Mane, 2011: p. 116). We should not fail to consider that the termination of dangerous behavior is a grim temporality such that, the mentally ill criminals are confined forever in mental institutions; many of them, leave only when they die. The justification for the permanency of the internee in the institution derives from the fact that the examination to detect the presence of dangerous behavior, attests that there is risk of harm to the individual himself or to society. For this reason, the security measure is renewed and may become a life sentence regime, as occurred with Febrônio Índio do Brasil and others (Fry, 1985). In this sense, the medical diagnostic equips the judge in taking the decision to cease or not the implementation of the security measure, i.e. the indetermination of the "time of deprivation of liberty by law demands the input of other domains of knowledge within the legal sphere: mental health, including psychology and psychiatry, social service and pedagogy. These offers of specialized knowledge subsidize the court decision”. (Whitaker, 2010: p. 40). By observing the dynamics of the completion of the implementation of the security measure, by hospital discharge, one realizes that this is a very complex process, not only by the departure from the institution, but by the possibilities of the individual to fit in, as a user of mental health services, in the different spaces conceived for such purposes, which, however operate in very precarious conditions. The point that deserves emphasis, regarding the hospital discharge policy, is the question of the social reintegration of the mentally ill criminal, clearly expressed in the 5th article of law No. 10.216, in the following terms: "the patient who has been hospitalized for a long time or characterized as being a situation of serious institutional dependence... will be the subject of specific policy of hospital discharge and assisted psychosocial rehabilitation.” (Mane, 2006: p. 215) Regarding this goal, one must draw attention to the following questions: 1 ) what in fact is the meaning of social reintegration? 2) how does one reintegrate, into society, individuals affected by their long stay in asylum institutions? and 3) what measures will be taken with respect to the difficulties of the individual in his personal reintegration journey? Such provocations should be considered, when one believes that the segregated are as they are due to the stigmas imputed upon them. In the case of mentally ill criminals, the stigmas are of a deeply derogative nature, reverberating in society and in the individual himself. When dealing with stigmatized people, the social context creates an environment favorable to the construction of scenarios that justify the stigma produced for the individual stigmatized by society. One of these scenarios is the use of the stigma theory as an ideal instrument of segregation. This mode of proceeding by the social context is closely linked to the Greek origin of the term stigma, whose meaning refers to bodily signs that attenuate something extraordinary or bad about someone's moral status (Duke, 2011). One must also take into consideration that the stigmatized, by having notion that they hold a stigma, creates disparaging representations of themselves, which can lead to the most diverse consequences, ranging from the appropriation of the stigma to take advantage in certain situations, to considerable subjective damages, resulting in a profound fall in their self-esteem. Without doubt, the mentally ill criminals represent characters that are stigmatized and under custody. The custody of mentally ill criminals for treatment is very problematic, due to the fact that the security measure is a legal procedure and the responsibility for treatment is based on medical expertise. Not always these two instances maintain a dialogue, mainly due to the fact that the institution for the treatment preserves physical characteristics and management of prison spaces. However, a paradoxical situation is evidenced with the end of hospitalization for adult people with mental disorders and in conflict with the law: One can no longer keep in custody for treatment. With the end of custody and treatment hospitals what will be the fate of anyone who commits a crime motivated by mental disorders? Up until this point, due to the crime, they are imprisoned for security reasons and managed in confinement systems. If we consider, however, the determinations of law 10.216, these individuals should be treated in the mental health services network and not hospitalized. This is the great impasse still without a solution. In the case of hospital discharge, how does one implement the possible terms for the released patient to obtain the benefits from the mental health service network? From this perspective, the research aims at producing a reflection regarding the policy for hospital discharge of mentally ill criminals, considering the possibilities of social reintegration; an analysis of the pertinence of public policies aimed at highlighting the importance of social apparatuses in the participation of the hospital discharge process of the mentally ill criminal; and to identify, within the reintegration process, what motivates the discharged patient with regards to the social context.

\section{Methodology}

For the purposes of this investigation a case study was used, conceived as a kind of systematic investigation of a 
specific instance. The key characteristic of this method is the emphasis on the uniqueness of the object of study, in terms of a detailed observation of a context or an individual, from a single source of documents or a specific event, being the reason for focusing on the records of Maria dos Anjos, who has a track record of nearly four decades in three different institutions: prison, asylum and mental hospital. Before identifying the peculiarities of this discharged patient, we present some biographical aspects and of her journey through different institutions, extracted from several anamneses in her records. Of a poor background, coming from the Northeast, lived with her mother, father and two brothers. She came to Rio de Janeiro to stay at a family home: her father had abandoned the family due to alcoholism and her mother claimed not to be able to bring her up because she was too disruptive. At the age of twelve she had her first sexual intercourse and began using drugs, being the reason for quitting school at the age of thirteen, without reaching the fourth grade of elementary school. With that same age she had her first hospitalization in a psychiatric clinic, for breaking her aunt's house. At the age of fifteen she was sent, by her aunt, to the Juvenile Court at Ilha do Governador, where she remained until she was nineteen, the age at which she began prostituting herself at the square called Praça Mauá and performing petty thefts to sustain herself. She became pregnant and, after birth, donated the baby, claiming that she had no conditions to care for the child. She became pregnant again and, according to the report from the maternity hospital Pró-Matre, the child was born dead; a version not accepted by Maria dos Anjos who claims to have seen her child healthy. This discrepancy was the reason for many clashes at the maternity hospital, culminated with her arrest when caught in a flagrant act of violence, attacking the face of a nurse with a piece of glass. After her imprisonment, due to a crisis, she was referred to a psychiatric institution, the Pedro II Hospital, where she killed an inmate who, in her version, had attacked her, but in fact this patient was under sedation. For this reason (absence of critical discernment), she was deemed incompetent to stand trial and sent to the Hospital Hector Carrillo for security reasons. The records of Maria dos Anjos, composed of three volumes, were transformed into a case study. Due to the large number of documents, one volume was initially chosen, which contained approximately six hundred pages, and from there were selected documents that would permit the understanding of the problematic issues involved in producing different diagnostics commencing with her first arrest until her hospital discharge. The aim is also to monitor the development of the different stigmas deriving from the generated diagnoses, paying attention to the characteristics and contradictions collated in the contents of the documents. The analysis of the documents proved to be a fruitful path to infer aspects of a life story, organized by facts that comprise the memory concerning the crossing of Maria dos Anjos through the institution. The richness of the documents, in terms of information, suggests that some measures taken did not produce the expected effects and, still, there are innumerous questions about the place where the patient should stay. In some documents a contrary indication clearly appears regarding the application of a security measure, suggesting that there would be a greater benefit if Maria dos Anjos was in a prison. Other documents, confirm a mentally ill criminal condition, which in fact prevailed until her discharge from hospital. Each document was considered in an isolated manner and followed by a read back of the information within its contents. Currently, despite being discharged, Maria dos Anjos still lives in the institution due to bureaucratic circumstances related to her documentation, which prevents her referral to a shelter or therapeutic residence. Neither does she have relatives who could collaborate in the process of social reintegration. With regard to the therapeutic residence, it comprises of a home where up to eight discharged individuals can live, preferably located near the CAPS or NAPS, or even close to their family residence. It must be pointed that, by law, all Therapeutic Residences needs to be supervised by CAPS or by a local outpatient Mental Health clinic and the interaction with the family of the discharged individuals is important with regard to the treatment and social reintegration. Thus, the following question arises: based on the knowledge of institutional issues of a clinical assistive nature, how will be the process of social reinsertion, considering that Maria dos Anjos has already been discharged? Like other discharged patients that remain in the institution, Maria dos Anjos is awaiting the services related to public health policies to enable conditions of coexistence in society. Without the help of relatives, this task becomes increasingly difficult, but not impossible.

\section{Results}

Several documents were analyzed from one volume of records related to Maria dos Anjos. The contents of these documents are varied, but mostly present information about her condition, diagnostic classifications and any episode that was highlighted according to reports by security agents, by doctors or by judges. The research focused on: 1) twenty-four referrals to a psychiatric clinic; 2) a sentence dated 1990; 3) a clinical report of examination of 
sanity in 1997; 4) a psychiatric diagnostic in 1995; 5) a psychiatric synopsis in 1993; 6) a psychiatric synopsis in 2007; and 7) an undated psychiatric synopsis. These documents reveal how the conditions of segregation reflected directly in the treatment of the patient, both negatively and positively. Based on a cataloging process, within six lines of analysis, one observes the existence of various documents that form the following themes: 1. Psychiatric referrals: a) eleven documents in 1991; b) ten documents in 1992; c) two documents in 1994; d) one document in 1995; 2. Aggression: a) one document indicating threat to others; b) three documents indicating aggressiveness; 3. Health: a) six documents); 4. Restraint of medication: a) one document suggesting medication addiction; b) two documents revealing possession of medicines; 5. Physical fighting: a) four documents; 6 . Turmoil: a) ten documents. The themes, threat to others, health, addiction to possessed medication, drug possession, aggression, physical fighting and turmoil, built up from the information contained in the referrals, are the characteristics concerning the patient which serve to justify the different diagnoses produced during her institutional track. In addition, some episodes are fundamental components in the assembly of the diagnoses, among which the following stand out: a) the constant commotion caused by the patient to the Pró-Matre maternity hospital, after having her first child and claiming the right to care for it, and b) the murder of a woman in the Hospital Pedro II. Both episodes are recorded in the records of Maria dos Anjos, and it is noteworthy that the aspects, portrayed in the themes and the mentioned episodes, are elements from which the medical diagnosis is used to construct a nosological scheme configured in diagnostic categories.

\section{Discussion of the Results}

The analyses of the documents reveal a patient in conflict, which hampers her interpersonal relationship with staff and other inmates. Often, the documents show her as: agitated, aggressive, impatient and addicted to retained medication. The contents of the documents show that it was difficult for the patient to adapt to the institutional norms, which several times, generated questioning by the health professionals, regarding the place (jail or mental institution) where the patient should stay as a result of the episodes which occurred and about the various diagnoses. In this respect, it should be highlighted, the existence of a psychiatric diagnosis, in the report of the patient, altered before being made official, making explicit the doubt of the professional who diagnosed her. The professional wrote by hand, "psychopathic personality" and then crossed out the term, writing "schizophrenia". In that same report there is a question about what would be best for the patient, thereby reproducing an ancient doubt, because as pointed out by Kummer (2010: p. 30), at the beginning of the 20th century, "some psychiatrists believe that the mental institutions should care for all the mentally ill, even criminals or those revealed as being dangerous. Others, on the contrary, tried to return the mentally ill criminals to the prisons”. Doubts about the place and the diagnosis however, did not shorten their suffering in the attempt to achieve the personal intention of finding a lost son. One also questions why the documents entitled referrals of patients to the psychiatric clinic, bring the impression of having been used for communication between shift workers and professionals of the social service sector, psychologists, psychiatrists and other healthcare professionals. In this respect, it is worth highlighting, by way of illustration, that, in the 1995 referral, the word "psychiatric" is crossed out and by its side is written the word "doctor", thus forming a new document to clinical medicine. With regard to the diagnoses included in the documents, we find: a) "bearer of psychopathy, capable of acts of extreme violence," diagnosis extracted from the sentence, withdrawn from an attached report, which however was not localized; b) "retarded mental development", in report of sanity. There are in this appraisal report reference to previous reports; c) "chronic schizophrenic profile", in a psychiatric diagnosis; d) the psychiatric synopsis in 1993 includes two diagnoses referenced by CID 10: 301.7/1 (personality disorders with predominance of sociopathic and asocial manifestations), and 301.3/9 (explosive personality disorder); d) a psychiatric synopsis of the year 2007, appears in the diagnosis CID-10 F, 20.1 (hebephrenic schizophrenia). In some documents, references were made to other CID's, as in the psychiatric synopsis in 1993, which linked the diagnosis to CID 9. It is also worth noting that the fact of the CID's having been changed is of fundamental importance for the construction of the memory of the institution, since it is necessary that mental health professionals be constantly updated in terms of knowledge regarding psychic illnesses. This means that new knowledge and diagnoses could be produced in terms of these recyclings, which, as can be observed in the case of Maria dos Anjos, caused impediments in the treatment. Nevertheless, when confronting the documentary impressions with the current state of the discharged patient, still sheltered however, one gets the clear impression that the person presentified in the documents differs from that which currently lives in the institution, suggesting the shadow of an unsolved case, and sometimes, in others, one perceives the discouragement 
of the medical care professionals with respect to the results of the treatment. Currently, Maria dos Anjos presents herself with a good degree of willingness to participate in the interviews, always very outgoing and friendly, but still with unresolved issues of a subjective nature, such as the dilemma between remaining in the institution and life outside; besides, also, expressing the fear of dying in the institution. Her current state suggests that, during her institutional track, therapeutic measures have produced positive results with regards to the control of her aggression and explosive behavior, as well as the contention of her delirious output. The great paradox that this case expresses consists in the fact that Maria dos Anjos is destined to continue sheltered, in an institution, in custody.

\section{Conclusion}

The long stay of Maria dos Anjos in different institutions has been responsible for her acquisition of inmate habits common to institutionalized individuals. These habits are expressed in her routine and might be seen as memory conditions, which are not always evident. They are fragments of life that step in existence. Therefore, the meaning of Maria dos Anjos' stories, along her narratives, is a mixture of experiences and fabulations.

The answers to the research questions in light of the theoretical framework used in this paper along with Maria dos Anjos' needs allow us to attest that to discharge a patient of a mental institution should not be limited to provide her a home or financial support; rather, a gamut of social apparatuses are required in order to bring these individuals back to society. To this end, both public health policies and society in general should fight for living together with different beings, regardless of the nature of their stigmas and differences that are attributed to them. Thus, a critical perspective is mandatory so that these people are not left on their own. On their long process to try to become social individuals again, those people come across conflictual and tense social situations, mainly the mentally ill criminals, since they have committed a crime. Maria dos Anjos' case study offers us a window through which it is possible to observe how the discharge experience has influenced the decisions over her life. Sometimes she expresses her willingness to stay in the institution, claiming that she loves to stay there. However, some time later, she cries and says she misses life outside the institution. It is for sure that she misses family support, which has never answered any of the institutional appointments. Nevertheless, it is crucial to examine carefully all the issues regarding individuals' maintenance beyond the institutional walls for those are precisely the ones concerning the social consequences that the different types of stigma will generate. As for Maria dos Anjos, her situation seems to be much more complex mainly because of the consequences stemming from her long path along different seclusion institutions.

The investigation in a forensic hospital provides a gamut of different research questions regarding the understanding of current institutional issues, an important factor for the memory construction of the institution. Besides, the institution has lately been under a transformation process: it is no longer a forensic hospital. Consequently purposes and practices have been transformed which have caused a set of guesses about the futures of those who remain there: inmates, discharged patients, mental health professional and management staff. All in all, it is worth highlighting that the institution has provided Maria dos Anjos some sort of structural organization in her life, mainly regarding her life projects that will be financially supported with the benefit she should get form the government.

Both authors are sponsored by the Brazilian national research sponsoring agency (CNPq). This study has been approved at the local IRB (0053.0.313.006-11).

\section{References}

Carrara, S. (1998). Crime e loucura. Rio de Janeiro: Eduerj.

Carrara, S. (2010). A história esquecida: os manicômios judiciários no Brasil. Rev. Bras. Crescimento Desenvolvimento Hum., 20, 16-29.

Castro, U. R. (2009). Reforma psiquiátrica e o louco infrator. Brasília: Hinterlândia.

Donzelot, J. (2001). A política das famílias. Rio de Janeiro: Graal.

Forti, V. (2009). Ética, crime \& loucura. Rio de Janeiro: Lumen \& Juris.

Foucault, M. (1996). História da loucura. São Paulo: Perspectiva.

Foucault, M. (2010). Vigiar e punir: o nascimento da prisão. Petrópolis: Vozes.

Foucault, M. (2011). O nascimento da clínica. Rio de Janeiro: Forense Universitária.

Fry, P. (1982). Febrônio Índio do Brasil: onde cruzam a psiquiatria, a profecia, a homossexualidade e a lei. In A. Eulálio 
(org.), Caminhos cruzados: Linguagem, Antropologia e Ciências Sociais. Rio de Janeiro. Brasiliense.

Fry, P. (1985). Direito positivo versus direito clássico: a psicologização do crime no Brasil no pensamento de Heitor Carrilho. In: S. A. Figueira (org.). Cultura da psicanálise. São Paulo: Brasiliense.

Gondar, J. (2005). Quatro proposições sobre memória social. In: J. Gondar e V. Dodebei (Orgs.). O que é memória social? Rio de Janeiro: Contra Capa.

Kummer, L. O. (2010). A psiquiatria forense e o Manicômio Judiciário do Rio Grande do Sul: 1925-1941. Tese de Doutorado Não-Publicada, Programa de Pós-Graduação em História, Universidade Federal do Rio Grande do Sul, Porto Alegre.

Lombroso, C. (2007). O homem delinquente. São Paulo: Ícone.

Mattos, V. (2006). Crime e psiquiatria: uma saída. Rio de Janeiro: Revan.

Mattos, V. (2011). Direito de quê? Notas sobre a ilegalidade da aplicação da medida de segurança. Psicologia em interface com a justiça e os direitos humanos. Conselho Federal de Psicologia. Brasília.

Mousse, L. B. (2008). Novos sujeitos de direito. Rio de Janeiro: Elsevier.

Neri, R. (2009). Enfraquecimento da lei ou aumento do poder punitivo? In S. Tedesco e M. L. Nascimento (Orgs.). Ética e subjetividade. Porto Alegre: Sulina.

Osman, R. (2008). Saúde mental: os direitos fundamentais. Rio de Janeiro: Espaço Artaud.

Pinto, D. S., Farias, F. R., \& Gondar, J. (2012). Experiência traumática: a construção de memória nos cenário do crime e da loucura. In D. S. Pinto e F. R. Farias (Orgs.), Novos Apontamentos em Memória Social. Rio de Janeiro: 7 Letras.

Rauter, C. (2009). Clínica e violência: construções e problematizações para uma clínica do contemporâneo. In S. Tedesco e M. L. Nascimento (Orgs.). Ética e subjetividade. Porto Alegre: Sulina.

Santos, N. M. W. (2010). História e loucura. Uberlância: EDUFU.

Whitaker, C. (2010). O campo infracional. São Paulo: Casa do Psicólogo. EDUFU.

Wolf, M. P. (2005). Antologia de vidas e histórias na prisão: emergência e injunção de controle social. Rio de Janeiro: Lumen \& Juris. 